\title{
Assessment of Water Losses from Badovc Lake, Kosovo: Hydrochemical Implications
}

\author{
Skender Bublaku ${ }^{1}$, Arjan Beqiraj ${ }^{1}$ and Agron Shala ${ }^{2}$ \\ 1. Faculty of Geology and Mining, Polytechnic University of Tirana, Tirana 1000, Albania \\ 2. Institute of Hydrometeorology of Kosovo, Kosovo Environmental Protection Agency, Prishtina 10000, Kosovo
}

\begin{abstract}
This paper aims to quantitatively assess water losses of Badovc Lake-Kosovo based on both water balance of the lake and water hydrochemistry. This attempt was strongly prompt by both the importance of this lake for water supply of Prishtina city and the lack of water. According to lake water balance, a water loss of 3,738,905 $\mathrm{m}^{3}$ and 1,722,552 $\mathrm{m}^{3}$ for the hydrologic year 2014 and the period January-May (2015) was evaluated. These consistent data favour the opinion that a continuous groundwater outflow from the lake is present and it is conditioned by the intensively developed fracture system in the lake basement formations. This was also supported by the chemical data (chloride, sulphate, hardness and electric conductivity etc.) of the water. Water from the leakages on the right side of the dam shows the same chemical signature as the water from the lake. Whereas, water from the piezometer, monitoring well and the gallery of Hajvalia mine show similar values with those of the water from the lake. The calculations of the chloride mass balance showed that the fractions of lake and rainfall waters in the water mixture of Hajvalia mine were $67 \%$ and $33 \%$ respectively.
\end{abstract}

Key words: Chloride, mass balance, rainfall, lake water balance, water inflow and outflow, water runoff.

\section{Introduction}

The Lake of Badove represents the main source for drinking water supply of Prishtina city. It was built in 1965 along the course flow of Graçancariver (Fig. 1). The geological formation where the dam is located is mostly composed of altered and fissured serpentinites with subordinate phyllite schist, clastic formations and gabbro-diabase rocks. A tectonic zone dipping just vertically is developed beneath the dam [1]. The catchment area of Badovc basin is about $104.1 \mathrm{~km}^{2}$ and lies between elevations $608 \mathrm{~m}$ and 1,200 $\mathrm{m}$ above sea level. It is characterized by a high vegetation cover where $90 \%$ are forests.

Three rivers (Mramor, Slivov and Androvina) drain their waters into Badovc Lake. The maximum values of surface and volume that correspond to water level 649.75 m.a.s.l. are $1.72 \mathrm{~km}^{2}$ and $25,590,000 \mathrm{~m}^{3}$ respectively. The average historical

Corresponding author: Arjan Beqiraj, professor, main research fields: hydrochemistry, earth and environmental sciences. E-mail: arjan.beqiraj@fgjm.edu.al. rainfall (1947-1994) was $647.36 \mathrm{~mm}$ [2], whereas the monitored rainfall for 2014 and the period January-May (2015) was $859.95 \mathrm{~mm}$ and $345.27 \mathrm{~mm}$ respectively. A difference of $3,738,905 \mathrm{~m}^{3}$ water in the lake water balance for the year 2014, between inflows and outflows, was attributed to water losses from the Lake [3-6]. A water loss of 1,722.522 $\mathrm{m}^{3}$ was found in the lake water balance for the period January-May, 2015 too. Two groundwater emergences along the right slopes of the dam represent the best visible groundwater outflow from the lake (Fig. 2).

Drainage of lake water to mine voids was also confirmed by the data of water chemistry. In particular, the conservative ion of chloride was applied to show the hydraulic connection between lake and other hydrologic components of the watershed. According to results of chloride mass balance, $67 \%$ of the Hajvalia mine water comes from the lake, while $32 \%$ from the rainfall. This investigation will help the decision making authorities to better manage the water 


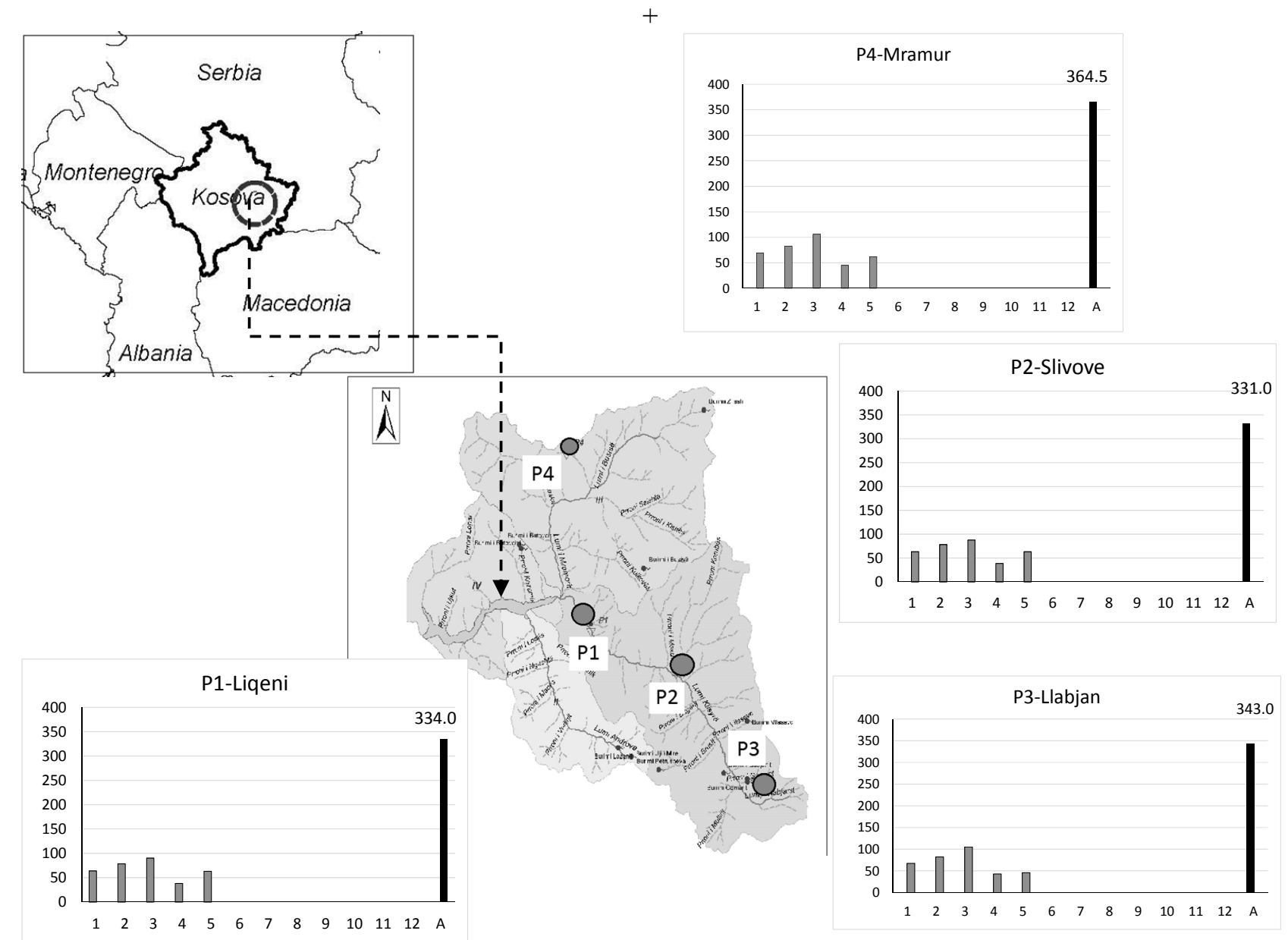

Fig. 1 Hydrologic basin of Badove Lake (Hydrographic and pluviometric network and monthly rainfall distribution for the year 2015 (January-May) are shown).

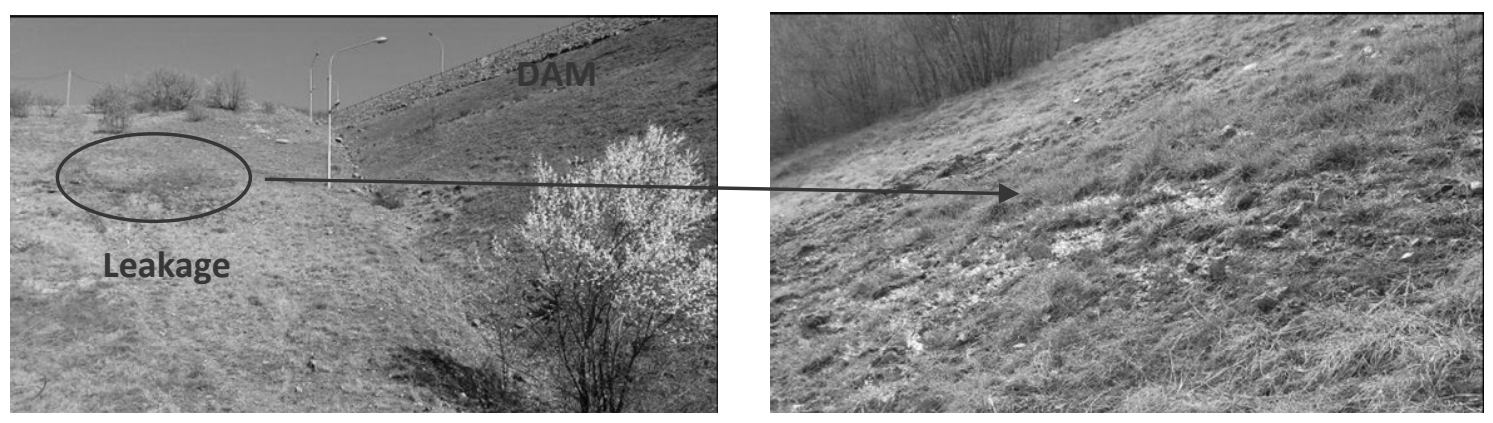

Fig. 2 Leakage of lake water on the right side of the dam.

of the lake and to undertake measures to prevent further loose of the water.

\section{Material and Methods}

A digital Hydrographical Echo Sunder-HydroBox 2010 device, with measuring frequency every $5 \mathrm{sec}$ was used for generating bathymetric data which were then interpolated by the Arc-GIS for the construction of the Lake bathymetry. In 2013, four manual rain gauges with diameter $250 \mathrm{~mm}$ have been installed for a daily monitoring of the rainfall in the basin. A continuous geodesic survey was applied for the monitoring of water level variations in the lake. The evaluation of the rivers flow was made across 
hydrometric regular profiles where the water speed was measured with Flowatch-JDC instrument. The daily abstraction of water from the lake was provided by water supplier of Prishtina. Amount of evaporation is made with a measurement standard evaporation pan located close to lake.

Water samples from all the hydrologic components of Badove lake were taken: four (B-4, B-5, B-6 and B-7) from the lake, two (B-9 and B-10) from leakages on the right side of the dam, two (B-12 and B-19) from the boreholes and two (B-13 and B-16) from the mine (Fig. 3). Sampling of water for chemical analysis in the lake and from wells was done with Staphylococcal Enterotoxin B Antiserum (SEBA) Liquid Sampler KLL-S. Chemical analysis are made in Chemical laboratory of the Institute of Hydrometeorology of Kosova.

\section{Results and Discussion}

\subsection{Hydrology of Badovc Basin}

During the period 2013-2015, several measurements of rainfall, water flows and evaporation etc. were made at Badovc basin aiming to determine water balance at the Lake. The bathymetry survey of the lake bottom was accomplished in October 2013.
At the end of this survey, the bathymetry model (Fig. 3) of the lake was constructed and the volume and surface curves were generated. In addition, a volume of 1,000,000 $\mathrm{m}^{3}$ mostly fine sediments was deposited on the bottom of the lake (near the dam) since its closure, which represents a depletion of $3.9 \%$ of the total $\left(25,590,000 \mathrm{~m}^{3}\right)$ water storage capacity of the lake. Annual amount of rainfalls for 2014, calculated according to the method of Thissenit [7] was $870.28 \mathrm{~mm}$. Whereas, during the observation period January-May (year 2015) was $345.27 \mathrm{~mm}$ (Fig. 1, Table 1).

\subsection{Water Inflow and Outflow of the Lake}

The annual water inflow into the lake for 2014 was 22,577,663 $\mathrm{m}^{3}[3,4]$ and it comprises: (i) River flow to the Lake (VS); (ii) Volume of runoff from the catchment (VR); (iii) Volume of direct precipitation on the lake (VP) and groundwater inflow (VGI). For the first five months January-May (2015), water inflow was $21,765,060 \mathrm{~m}^{3}$. The total volume of water that flew into the lake through three independent perennial tributary rivers (VS) during the above observation period (January-May, 2015) was $18,493,705 \mathrm{~m}^{3}$ and represents about $85 \%$ of the total water inflow into the lake (Table 2). In the same period, the direct surface

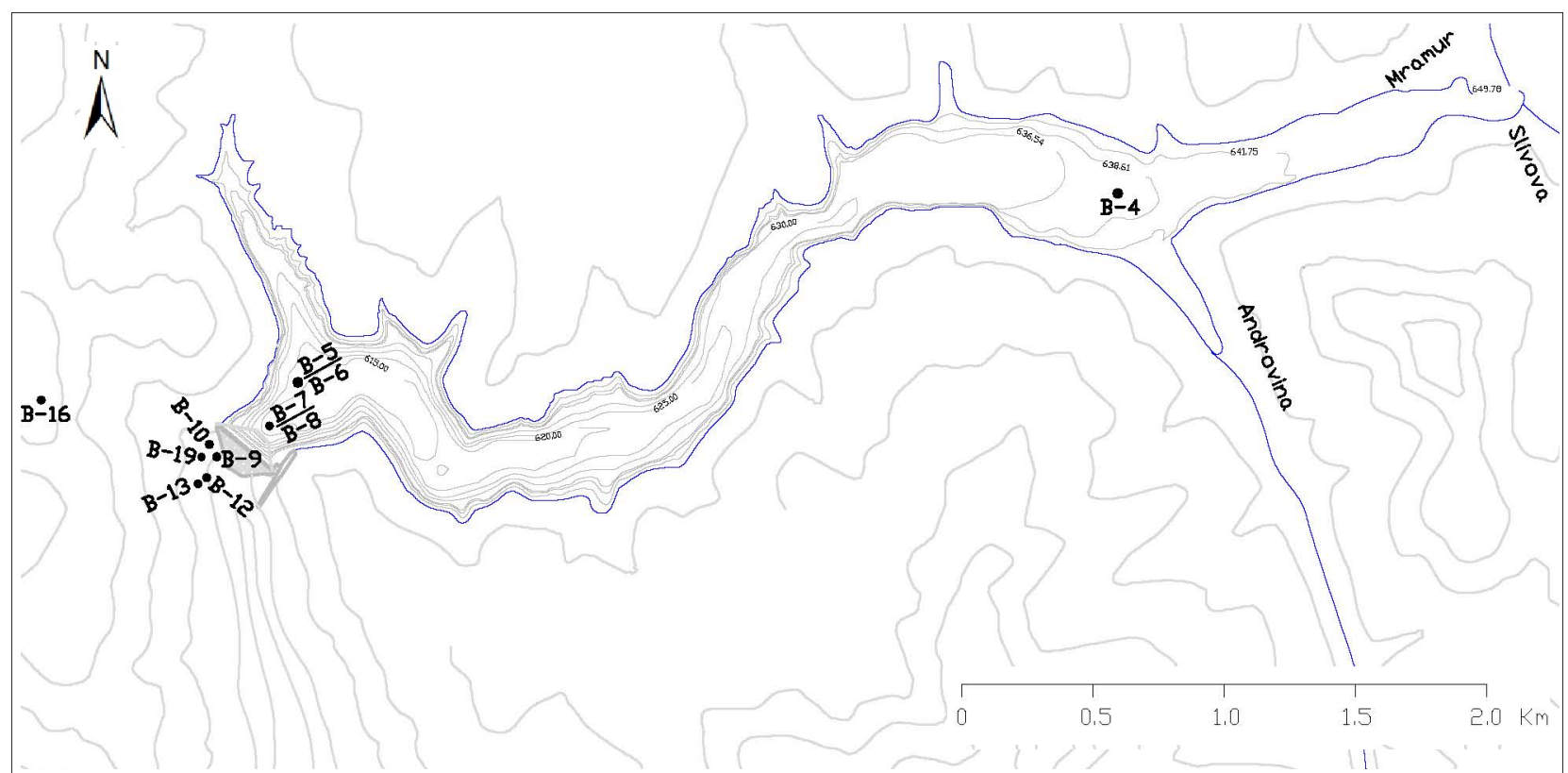

Fig. 3 Bathymetric map of the Badove Lake where location of water samples is shown. 
Table 1 Annual rainfall (in mm) for the Badove basin (January-May, 2015).

\begin{tabular}{lllll}
\hline Pluviometer station & $\mathrm{P}_{1}$ & $\mathrm{P}_{2}$ & $\mathrm{P}_{3}$ & $\mathrm{P}_{4}$ \\
\hline Precipitation by station & 334.0 & 331.0 & 343.0 & 364.2 \\
Basin precipitation & 345.27 & & & \\
\hline
\end{tabular}

Table 2 Volume of water inflow (January-May, 2015).

\begin{tabular}{lllll}
\hline Month & $\mathrm{V}_{\mathrm{S}}$ & $\mathrm{V}_{\mathrm{R}}$ & $\mathrm{V}_{\mathrm{P}}$ & Total \\
\hline January & $3,159,145$ & 472,924 & 54,145 & $3,686,214$ \\
February & $4,391,712$ & 657,439 & 125,600 & $5,174,751$ \\
March & $6,613,013$ & 989,968 & 150,801 & $7,753,782$ \\
April & $2,916,120$ & 436,543 & 65,493 & $3,418,156$ \\
May & $1,413,716$ & 211,633 & 106,808 & $1,732,157$ \\
January-May & $18,493,705$ & $2,768,508$ & 502,847 & $21,765,060$ \\
Total Inflow & $21,765,060$ & & & \\
\hline
\end{tabular}

Table 3 Volume of water outflow (January-May, 2015).

\begin{tabular}{llllll}
\hline Month & $\mathrm{V}_{\mathrm{A}}$ & $\mathrm{V}_{\mathrm{GO}}$ & $\mathrm{V}_{\mathrm{E}}$ & $\mathrm{V}_{\mathrm{OF}}$ & Total \\
\hline January & $1,020,000$ & 10,714 & 14,700 & $/$ & $1,045,414$ \\
February & 880,000 & 10,714 & 32,000 & $/$ & 922,714 \\
March & $1,002,333$ & 10,714 & 58,450 & $2,800,000$ & $3,871,497$ \\
April & $1,080,000$ & 13,392 & 141,930 & $1,806,588$ & $3,041,910$ \\
May & $1,180,000$ & 10,714 & 192,660 & 91,600 & $1,474,974$ \\
January-May & $5,162,333$ & 56,246 & 439,740 & $4,698,188$ & $10,356,508$ \\
Outflow 2015 & $10,356,508$ & & & & \\
\hline
\end{tabular}

runoff flow (VR) to lake [8] is $2,738,508 \mathrm{~m}^{3}$ and represents about $12.7 \%$ of the total runoff of the Badove basin. The volume of rain water (VP) falling direct over the lake surface was estimated to be $502,847 \mathrm{~m}^{3}$ and represents about 2.3\% (Table 2) of the total water inflow.

The water outflow from the lake is comprises of evaporation from the lake surface (VE), water abstraction (VA) and infiltration of water from the lake bottom (VGO). The overflow from the lake (VOF) represents an additional component of the water outflow from the lake.

The total volume of water outflow from the lake over the hydrologic year 2014 was $11,494,758 \mathrm{~m}^{3}$ [4], while for the first five months January-May (year 2015), water outflow was $10,356.508 \mathrm{~m}^{3}$. Water abstracted from the lake (VA) during the above period, used for household purpose was 5,162,333 $\mathrm{m}^{3}$ (Table 3 ). The volume of water evaporated from the lake surface (VE) for the same period was $439,740 \mathrm{~m}^{3}$ and represents $252 \mathrm{~mm}$. Groundwater flow to (VGI) or from (VGO) the lake is an important component of the lake water balance and the most difficult to quantify as it cannot be measured directly [9].

The designed water infiltration from the lake dam for January-May (year 2015) was 56,246 $\mathrm{m}^{3}$ (Table 3). During the month March-April (year 2015), an amount of $4,698,188 \mathrm{~m}^{3}$ overflew (VOF) the dam of the lake because the water level in the lake raised above its maximum level (Table 3).

\subsection{Lake Water Balance}

The water balance equations are based on the premise that the difference between water inflow and water outflow over a given time period for the hydrologic system of a lake must equal to the change in water storage in that system [10]. All of lake water gains and losses and the corresponding changes in the 
measured lake level over the above period are taken into account in order to compute the lake water budget, as it appears in Eq. (1) [9]:

$$
\begin{aligned}
\Delta V= & (V P+V R+V S+V G I)- \\
& (V A+V G O+V O F)
\end{aligned}
$$

Where,

$\Delta V=$ change in lake volume $\left(\mathrm{m}^{3}\right)$;

$V P=$ precipitation on the lake $\left(\mathrm{m}^{3}\right)$;

$V R=$ surface runoff from the catchment $\left(\mathrm{m}^{3}\right)$;

$V S=$ stream flow to the lake $\left(\mathrm{m}^{3}\right)$;

$V G I=$ groundwater inflow to the lake $\left(\mathrm{m}^{3}\right)$;

$V A=$ abstraction from the lake $\left(\mathrm{m}^{3}\right)$;

$V E=$ water evaporation from the lake $\left(\mathrm{m}^{3}\right)$;

$V G O=$ groundwater outflow from the lake $\left(\mathrm{m}^{3}\right)$;

$V O F=$ overflow from the lake $\left(\mathrm{m}^{3}\right)$.

Changes in the water volume of Lake are calculated based on the fluctuations of water level in the Lake which, in turn, are a function of the balance between precipitation on the lake, runoff to the lake, evaporation, abstraction and groundwater outflow from the lake [11]. Water volume in Badovc Lake on January 1, 2014 was 9,509,000 $\mathrm{m}^{3}$ while on December 31,2014 , it was $16,853,000 \mathrm{~m}^{3}$ that corresponds to water level $637.15 \mathrm{~m}$ and 643.60 m.a.s.l (Fig. 4) respectively. In May 31 2015, water volume was $26,539,000 \mathrm{~m}^{3}$ (Table 4) that corresponds to water level 649.70 m.a.s.l (Fig. 4). The change of water volume in 2014 was 7,344,000 $\mathrm{m}^{3}$ while in January-May (year 2015) was 9,686,000 $\mathrm{m}^{3}$ (Table 4, Fig. 5).

\subsection{Water Loss from the Lake}

The results of Badovc lake water balance in 2014 showed that a difference in water volume of $3,738,905$ $\mathrm{m}^{3}$ between inflow into the Lake and outflow from the Lake existed. This amount represents about $17 \%$ of annual inflow into the Lake for 2014 and is considered as water loss from Lake $[3,4]$. The water loss during the period January-May 2015 was 1,722,552 $\mathrm{m}^{3}$ (Table 4) which is similar with that found for the same time period of the year 2014. Such a consistent difference in the water balance of the lake confirms that a continuous groundwater outflow from the lake happens and it is conditioned by the intensively developed fracture system.

\subsection{Chemical Evidences of Water Lose}

The above groundwater outflow, which represents the water loss from the Badovc Lake, was considered to drain mostly into the Hajvalia mine voids [3-5]. In order to confirm this opinion, the data of chemical analysis from several hydrological water components

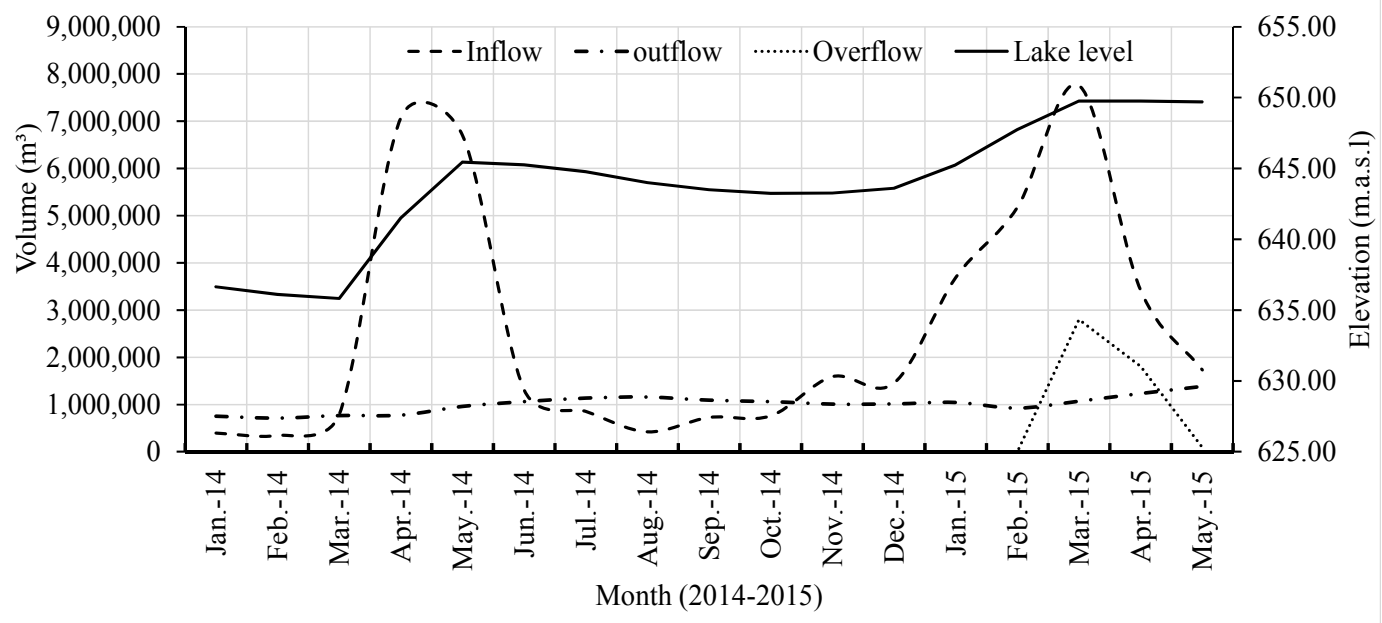

Fig. 4 Volume inflow, outflow, overflow and lake water level during 2014 and 2015. 
Table 4 Monthly water balance for the Badove Lake (January-May, 2015).

\begin{tabular}{lllllllll}
\hline \multirow{2}{*}{ Month } & $\begin{array}{l}\text { Level } \\
(\mathrm{m} . \mathrm{a} . \mathrm{s} .1)\end{array}$ & $\begin{array}{l}\text { Inflow } \\
\left(\mathrm{m}^{3}\right)\end{array}$ & $\begin{array}{l}\text { Outflow } \\
\left(\mathrm{m}^{3}\right)\end{array}$ & $\begin{array}{l}\text { Volume of } \\
\text { lake }\left(\mathrm{m}^{3}\right)\end{array}$ & $\begin{array}{l}\text { Volume } \\
\text { change in the } \\
\text { lake }\left(\mathrm{m}^{3}\right)\end{array}$ & Overflow $\left(\mathrm{m}^{3}\right)$ & $\begin{array}{l}\text { Inflow-Outflo } \\
\mathrm{w}\left(\mathrm{m}^{3}\right)\end{array}$ & $\begin{array}{l}\text { Groundwater } \\
\text { outflow }(\text { losses }) \\
\left(\mathrm{m}^{3}\right)\end{array}$ \\
\cline { 2 - 9 } & 0 & 1 & 2 & 3 & 4 & 5 & $6=(1)-(2) \begin{array}{l}7=(4)+(5)- \\
(6)\end{array}$ \\
\hline January & 643.60 & $3,686,214$ & $1,045,414$ & $19,131,000$ & $2,278,000$ & 0 & $2,640,800$ & $-362,800$ \\
February & 645.25 & $5,174,751$ & 922,714 & $22,991,000$ & $3,860,000$ & 0 & $4,252,038$ & $-392,038$ \\
23-March & 649.75 & $4,569,203$ & 794,982 & $26,590,000$ & $3,599,000$ & 0 & $3,774,222$ & $-175,222$ \\
31-March & 649.75 & $3,184,578$ & 276,515 & $26,590,000$ & 0 & $2,800,000$ & $2,908,063$ & $-108,063$ \\
April & 649.75 & $3,418,156$ & $1,235,322$ & $26,590,000$ & 0 & $1,806,588$ & $2,182,834$ & $-376,246$ \\
15-May & 649.75 & 898,251 & 669,374 & $26,590,000$ & 0 & 91,600 & 228,877 & $-137,277$ \\
31-May & 649.72 & 833,906 & 713,999 & $26,539,000$ & $-51,000$ & & 119,907 & $-170,907$ \\
Jan.-May & & $21,765,060$ & $5,658,320$ & & $9,686,000$ & $4,698,188$ & $16,106,740$ & $-1,722,552$ \\
\hline
\end{tabular}

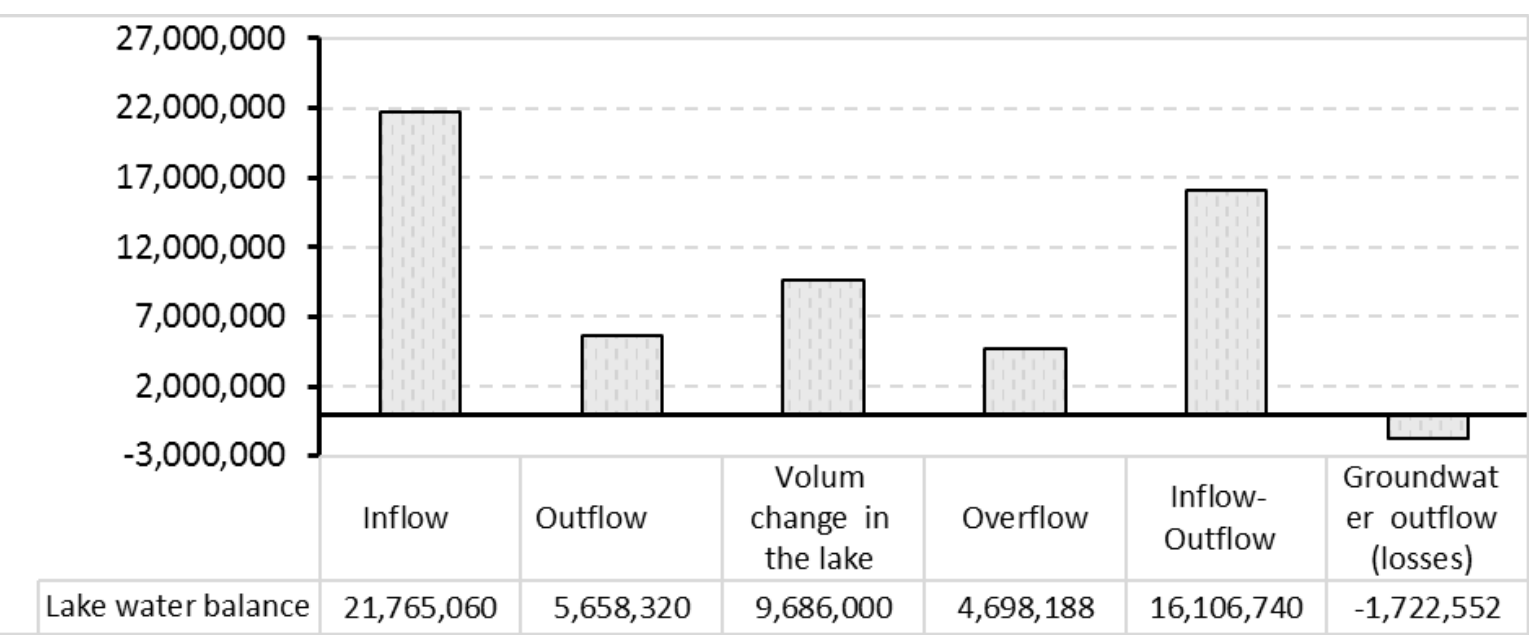

Fig. 5 Water balance for the Badove Lake (January-May, 2015).

of the Badovc watershed were confronted. In general, solutes that are present in groundwater are derived from two main sources [12]: (1) inputs from atmospheric precipitations and (2) acquisition during weathering and water-rock interaction. According to their behaviour, the chemical signatures are divided into inert and reactive tracers and they may be used effectively to derive physical parameters such as recharge rates and mixing [13]. Among the inert tracers, chloride is the most useful because it is highly mobile and is not involved in the common geochemical reactions that occur in groundwater. In addition, chloride is a conservative element with a mobility in water very similar to the water molecules [14]. Based on the chloride content in the sampled waters (Table 5, Fig 6), it may be seen the strong influence of the lake water in the waters from leakages on the right side of the dam, piezometer and Hajvalia mine gallery. At the same conclusion could be arrived considering the content of sulphates and values of general hardness and electric conductivity of the water (Table 5, Figs. 7-9). Thus, water from the leakages, piezometer and Hajvalia mine gallery may represent a mixture between lake and rainfall waters. In this case, mixing between two waters may often be estimated from a simple mass balance as from Herczeg and Edmunds [13]:

$$
[C l]_{\mathrm{M}}=x \times[C l]_{\mathrm{A}}+(1-x) \times[C l]_{\mathrm{B}}
$$

Where, $[\mathrm{Cl}]_{\mathrm{M}}$ is the $\mathrm{Cl}$ concentration in the mixture (water of Hajvalia mine gallery), $\mathrm{x}$ is the fraction of water $A$ (rainfall water, $C l=1.92 \mathrm{mg} / \mathrm{L}$ )) and $1-\mathrm{x}$ is the fraction of water mass B (lake water, B-4, B-5, 
B-6 and B-7). With assumption that the mixing process is conservative with respect to solutes, water fractions of rainfall and lake mixed to give water of Hajvalia mine gallery were evaluated to be $33 \%$ and $67 \%$ respectively. In the case of water leakages (B-9 and B-10), the fractions of rainfall and lake water are estimated to be $8 \%$ and $92 \%$ respectively, showing a stronger influence of the lake water. The fractions of lake and rainfall water in the mixture depends on the seasons when the measurements are made. One could expect higher influence of water from lake during the drying periods and vice versa. Finally, the extent of lake water influence in other water drainages is conditioned by the permeability of fracture systems that serves as pathways for ground water flow.

\section{Conclusions}

The lake of Badove is characterized by a consistent water loss caused by the groundwater outflow from the lake thanks to intensive fracture system developed

Table 5 Chemical composition of water.

\begin{tabular}{|c|c|c|c|c|c|c|c|c|c|c|c|}
\hline Parameters & Unit & B-4 & B-5 & B-6 & B-7 & B-9 & $\mathrm{B}-10$ & B-19 & B-12 & B-13 & B-16 \\
\hline Temperature & ${ }^{\circ} \mathrm{C}$ & 15 & 13.5 & 9.5 & 12.5 & 15.7 & 15.5 & - & 13.7 & 14.1 & 22.8 \\
\hline $\mathrm{pH}$ & & 9.7 & 9.9 & 8.2 & 9.5 & 5.7 & 5.5 & 7.76 & 8.37 & 8.1 & 6.56 \\
\hline Dissolved oxygen & $\mathrm{mg} / \mathrm{L}$ & 8.66 & 8.71 & - & 8.7 & 7.44 & 7.41 & - & 4 & 7.3 & 1.1 \\
\hline Electric conductivity & $\mu \mathrm{S} / \mathrm{cm}$ & 317 & 263 & 271 & 250 & 264 & 262 & 455 & 746 & 1,030 & 1,703 \\
\hline Total dissolved solids & $\mathrm{mg} / \mathrm{L}$ & 159 & 138 & 135 & 126 & 134 & 133 & 227 & 375 & 515 & 852 \\
\hline General hardness & $\mathrm{d}^{\circ} \mathrm{H}$ & 12.15 & 12.01 & 11.26 & 11.76 & 11.56 & 11.91 & 15.18 & 30.03 & 40.81 & 58.4 \\
\hline $\mathrm{Ca}^{2+}$ & $\mathrm{mg} / \mathrm{L}$ & 58.14 & 57.53 & 52.93 & 56.13 & 22.05 & 19.44 & 24.1 & 24.46 & 56.94 & 281 \\
\hline $\mathrm{Mg}^{2+}$ & $\mathrm{mg} / \mathrm{L}$ & 24.31 & 23.98 & 23.3 & 23.62 & 51.12 & 55.43 & 71.3 & 160.5 & 198.1 & 116 \\
\hline $\mathrm{Na}^{+}$ & $\mathrm{mg} / \mathrm{L}$ & 4.101 & 4.086 & 4.176 & 4.083 & 2.846 & 2.869 & 2.797 & 6.316 & 4.528 & 22.1 \\
\hline $\mathrm{K}^{+}$ & $\mathrm{mg} / \mathrm{L}$ & 2.244 & 2.319 & 2.484 & 2.251 & 0.14 & 0.227 & 0.294 & 4.144 & 2.994 & 26.1 \\
\hline $\mathrm{NH}_{4}^{+}$ & $\mathrm{mg} / \mathrm{L}$ & nd & nd & nd & nd & 0.585 & nd & 0.011 & nd & nd & nd \\
\hline $\mathrm{NO}_{2}^{-}$ & $\mathrm{mg} / \mathrm{L}$ & 0.141 & 0.133 & 0.109 & 0.137 & 0.148 & 0.19 & 0.038 & 0.075 & 0.126 & 0.1 \\
\hline $\mathrm{NO}_{3}^{-}$ & $\mathrm{mg} / \mathrm{L}$ & 0.3 & 0.3 & 0.3 & 0.3 & 0.2 & 0.3 & 0.3 & 1 & 0.7 & 0.2 \\
\hline $\mathrm{HCO}_{3}^{-}$ & $\mathrm{mg} / \mathrm{L}$ & 245.2 & 251.3 & 226.9 & 228.1 & 259.9 & 258.6 & 361 & 568.5 & 789.3 & 921 \\
\hline $\mathrm{SO}_{4}{ }^{2-}$ & $\mathrm{mg} / \mathrm{L}$ & 35.5 & 35.4 & 40.4 & 43.6 & 39.1 & 48.9 & 36.7 & 232 & 269.7 & 435 \\
\hline $\mathrm{Cl}^{-}$ & $\mathrm{mg} / \mathrm{L}$ & 11.1 & 11.35 & 11.46 & 11.31 & 10.38 & 10.4 & 13.25 & 6.37 & 8.09 & 18.8 \\
\hline $\mathrm{PO}_{4}{ }^{3-}$ & $\mathrm{mg} / \mathrm{L}$ & $<0.01$ & $<0.01$ & $<0.01$ & $<0.01$ & $<0.01$ & $<0.01$ & 0.099 & $<0.01$ & 0.06 & $<0.01$ \\
\hline $\mathrm{H}_{2} \mathrm{SiO}_{3}$ & $\mathrm{mg} / \mathrm{L}$ & 0.997 & nd & nd & 0.034 & 0.777 & 1.859 & 0.91 & 14.03 & 0.86 & 4.23 \\
\hline
\end{tabular}

$\mathrm{Cl}^{-}$

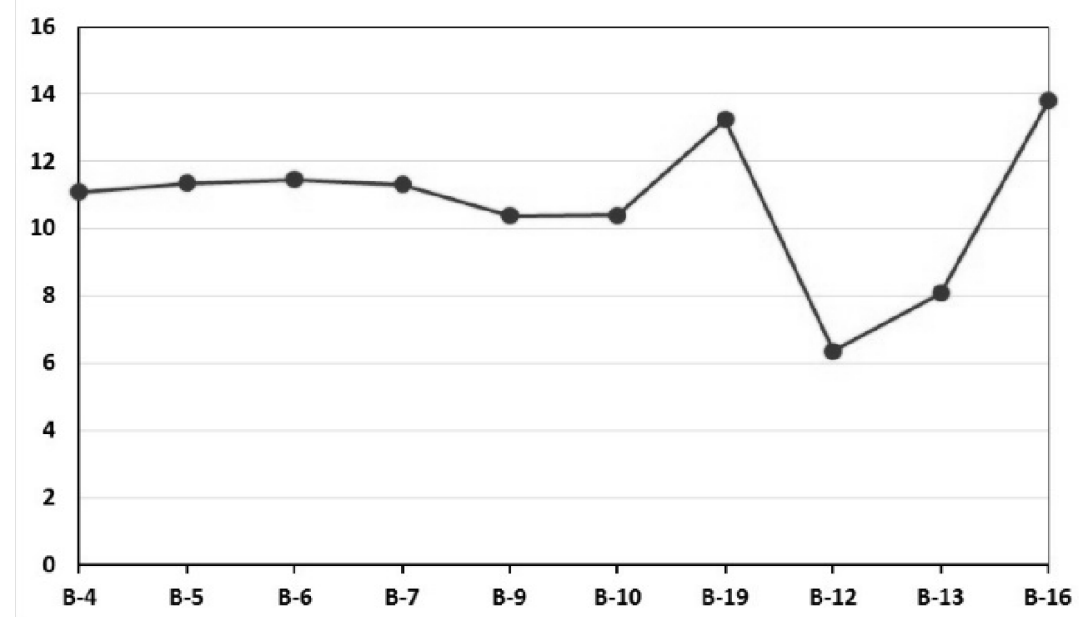

Fig. 6 Variation of chloride content in the waters from different sites of Lake Badove. 


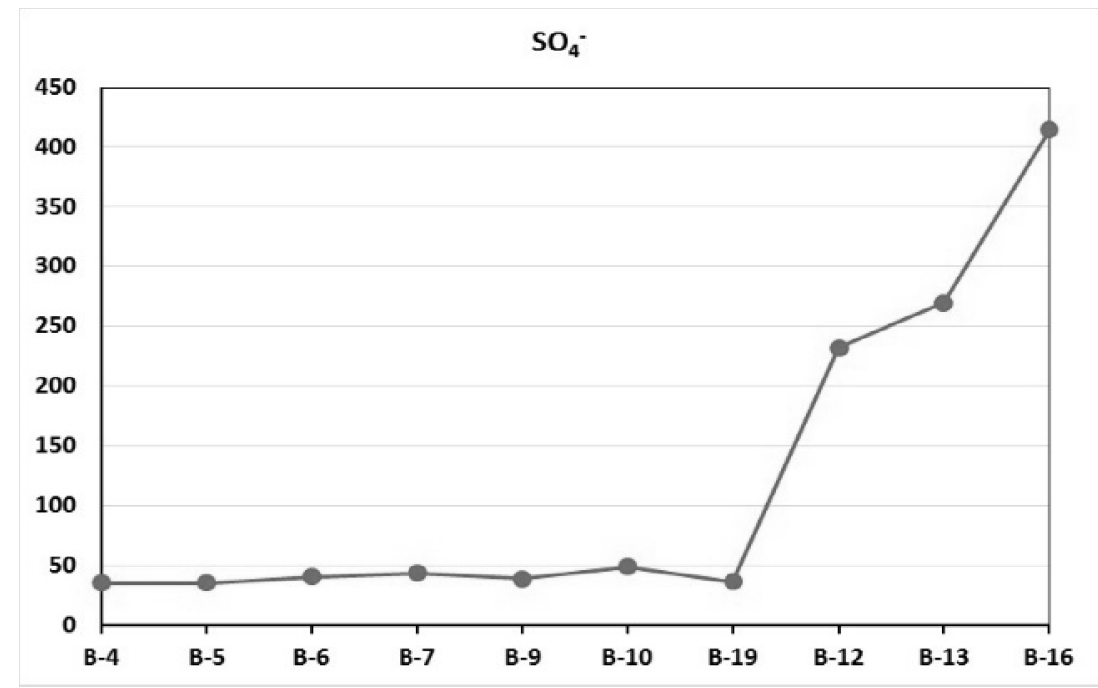

Fig. 7 Variation of sulphide content in the waters from different sites of Lake Badove.

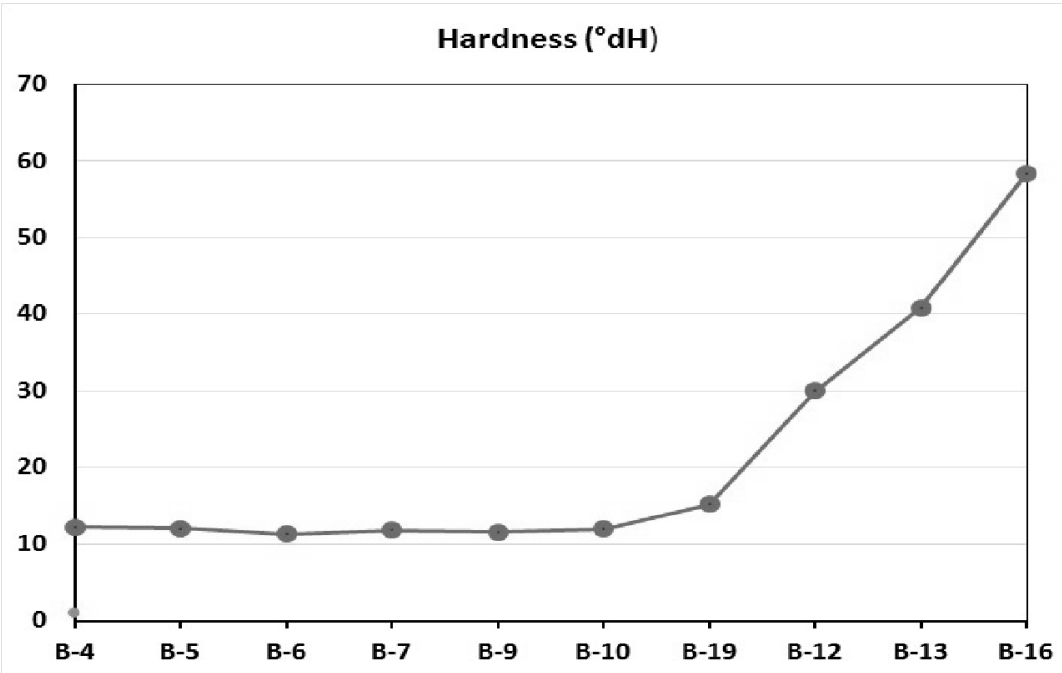

Fig. 8 Variation of hardness values in the waters from different sites of Lake Badove.

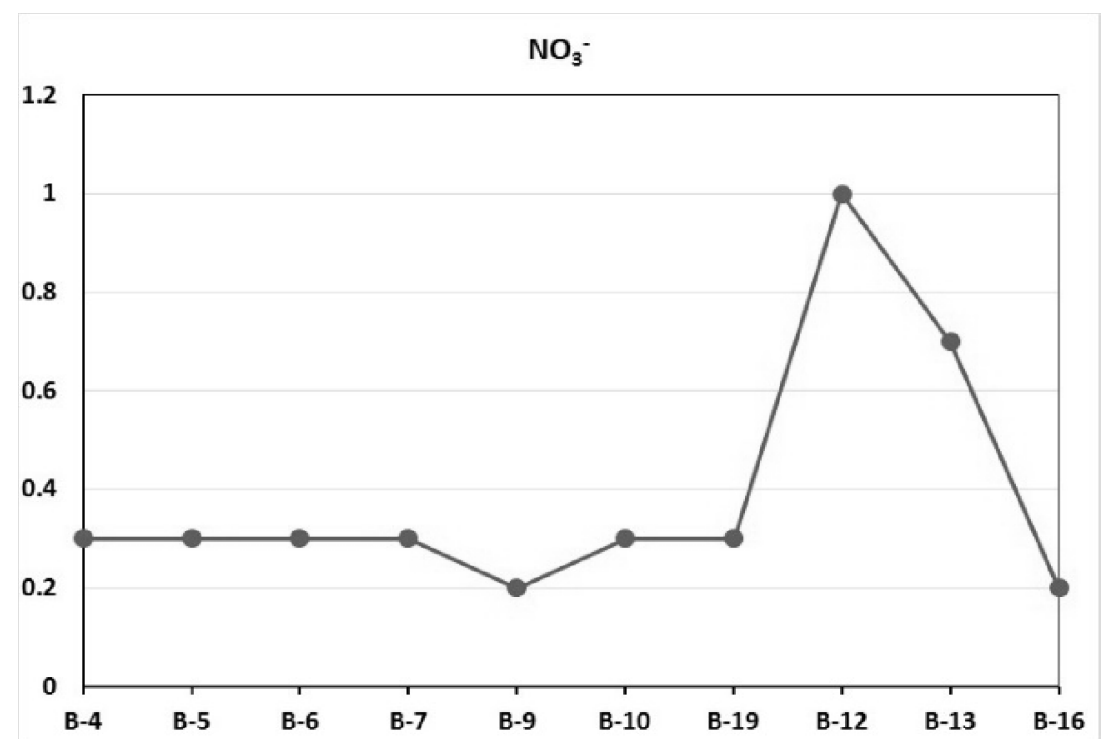

Fig. 9 Variation of nitrate content in the waters from different sites of Lake Badove. 
through the lake basement geological formations. This water loss represents about $17 \%$ of the total water inflow into the lake. The water emergences on the right side of the dam represent the best visible exhibition of the groundwater outflow from the lake. The chemical signatures of water further supported the loss of water from the lake.

The water from the gallery of Hajvalia mine represents a mixture of lake and rainfall water in proportions $67 \%$ and $33 \%$ respectively.

\section{Acknowledgments}

The authors would like to express special gratitude to technical and administrative staff of Regional Water Company "Prishtina" J.S.C. and surveying staff of the Badove Lake for providing the authors with data on abstraction rates and the permission to perform different hydro-meteorological measurements.

\section{References}

[1] Institute of Hydro-Economy "Jarosllav Çerni”. 1982. Characteristics of Water Resources, Geology and Hydrogeology. Research report.

[2] Hydrometerological Institute of Kosovo (HIK). 2014. Data on Rainfalls for the Period 2000-2014. Annual report.

[3] Bublaku, S., Beqiraj, A., and Çadraku, H. 2015. "The Influence of Geological Conditions on the Badove Lake Water Balance, Kosovo.” Bul. Shk. Gjeol. 1: 1-8.

[4] Bublaku, S., and Beqiraj, A. 2015 "Water Balance and Water Loss Implications in Badovclake, Kosovo."
Journal of Geography and Earth Sciences 3: 1.

[5] Bublaku, S., and Beqiraj, A. 2015. Assessment of Water Balance for Badovclake-Kosovo. Spain: Water Resources Management.

[6] Bublaku, S., and Beqiraj, A. 2014. "Preliminary Indications on the Factors Influencing the Unexpected Water Level Lowering at Badovc Lake, Kosovo." In Proceedings of CBGA 2014, 106.

[7] Show E. M. 2005. Hydrology in Practice. England: Tazlor and Francis E-Library.

[8] Brian, P. Neff, and Jason, R. Killian. 2003. The Great Lakes Water Balance: Data Availability and Annotated Bibliography of Selected References. Water Resources Investigations report.

[9] Gebreslase, M. S. H., Hagos, Y. E., and Samuel, G. 2012. Lake Water Balance. Germany: Lambert Academic Publishing.

[10] Radwan, G. A. 2009. Using Hzdrological and Meteorological Data for Computing the Water Budget in lake Qarum, Egypt. Egypt: National Institute of Oceanography and Fisheries.

[11] Van, Der, Kamp, G., Keir, D., and Evans, M. 2008. "Long-term Water Level Changes in Closed Basin Lakes of the Canadian Prairies." Canadian Water Resources Journal 33 (1): 23-38.

[12] Cook, P. G., and Herczeg, A. L. 2000. Environmental Tracers in Subsurface Hydrology. New York: Springer Science and Business Media.

[13] Herczeg, A. L., and Edmunds, W. M. 2000. "Inorganic ions as Tracers." In Environmental Tracers in Subsurface Hydrology, edited by Peter, G. Cook, and Andrew, L. Herczeg. New York: Springer Science and Business Media.

[14] Hill, D. 1984. "Diffusion Coefficients of Nitrate, Chloride, Sulphate and Water in Cracked and Uncracked Chalk." J. Soil Sci. 35: 27-33. 